\title{
Two cases of multiple ossifying fibromas in the jaws
}

Ting-Ting Wang ${ }^{1+}$, Ran Zhang ${ }^{2 \dagger}$, Lin Wang ${ }^{1 *}$, Yan Chen², Qing Dong ${ }^{1}$ and Tie-Jun $\mathrm{Li}^{2,3,4^{*}}$

\begin{abstract}
Background: The clinicopathologic characteristics of multiple ossifying fibroma (OF) are unclear due to the condition's rarity, making diagnosis challenging. Sporadic multiple OFs must be distinguished from hyperparathyroidism-jaw tumour syndrome (HPT-JT) related OF and other fibro-osseous lesions.

Methods: Multiple OF cases were identified from ossifying fibroma cases. Clinical data including age, sex, anatomic site, radiographic features, clinical impression, treatment and available follow-up data as well as serum calcium, phosphorus, and parathyroid hormone (PTH) were recorded. GNAS and HRPT2 genetic mutations were examined in the two present cases. Case reports of sporadic multiple ossifying fibroma and HPT-JT-related OF were also reviewed.
\end{abstract}

Results: The two present cases were confirmed as sporadic multiple OF, with no genetic GNAS and HRPT2 mutations found. The incidence of sporadic multiple ossifying fibroma was $2.0 \%(2 / 102)$. The total 18 sporadic multiform OF cases were characterized as followed: 13 (72.2\%) female; 5 (27.8\%) male; mean age 28.6 years; 2/16 (11.1\%) cases only in the mandible; 4/18 (22.2\%) cases only in the maxilla; and 12/18 (66.7\%) cases in both the maxilla and mandible. Radiographically, the lesions were radiolucent in 5/18 (27.8\%) cases and mixed density in 13/18 (72.2\%) cases. Along with 24 cases of HPT-JT related OF were reviewed, sixteen (66.7\%) patients were diagnosed with a single lesion, and 8 patients (33.3\%) were diagnosed with multiple jaw lesions.

Conclusions: Sporadic multiple OFs are very rare, but must be distinguished from HPT-JT related OF. We strongly recommend that patients diagnosed with multiple ossifying fibromas receive serum PTH testing and mutation screening of HRPT2.

Virtual slides: http://www.diagnosticpathology.diagnomx.eu/vs/1194507146115753

Keywords: Multiple ossifying fibroma, HPT-JT, Fibrous dysplasia, GNAS gene, HRPT2 gene, Osseous dysplasia

\section{Background}

Benign fibro-osseous lesions (BFOL) are a clinically diverse group of bone disorders that share similar histologic features and occur relatively commonly in the jaw. Common to all forms of BFOL is the replacement of normal bone with a tissue comprising collagen and fibroblasts containing varying amounts of mineralized substance, which may be bony or cementum-like in appearance. BFOL include

\footnotetext{
* Correspondence: wangl60@163.com; litiejun22@vip.sina.com

${ }^{\dagger}$ Equal contributors

'Department of Oral Medicine, Hebei United University, School and Hospital of Stomatology, Tangshan, 82 South Construction Road, Hebei 063000, Lubei District, PR China

${ }^{2}$ Department of Oral Pathology, Peking University School and Hospital of Stomatology, 22 South Zhongguancun Avenue, Haidian District, Beijing 100081, PR China

Full list of author information is available at the end of the article
}

developmental lesions, reactive or dysplastic processes, and neoplasms [1,2]. Ossifying fibroma (OF), fibrous dysplasia (FD), and osseous dysplasia (OD) are three forms of BFOL. The most common OF lesions including conventional and juvenile types that typically occur in the premolar-molar region of the mandible, with women more frequently affected [3]. OF is generally asymptomatic, but can cause serious cosmetic and functional problems [4]. Ossifying fibroma can present as a solitary lesion or rarely, as multiple lesions.

OF and FD show distinct patterns of disease progression, and it is important to distinguish between them. OF carries a risk of recurrence and must be completely enucleated from the surrounding bone. By contrast, FD growth usually stabilizes when skeletal maturity is reached; hence, surgical 
intervention is usually reserved for cosmetic or functional purposes [5-7]. However, these two lesions present diagnostic difficulties because of the uncertain significance of specific radiological and histological features, especially in biopsied specimens, and therefore, accurate diagnosis can be challenging. WHO has suggested three subtypes of fibrous dysplasia as follows: monostotic fibrous dysplasia (MFD), which involves only one bone; polyostotic fibrous dysplasia (PFD), which involves multiple bones; and McCune-Albright syndrome (MAS), which has at least two of the following triad: PFD, café-au-lait spots, and hyperfunctional endocrinopathy (such as precocious puberty, hyperthyroidism, growth hormone excess, and Cushing's syndrome). Multiple bone involvement is more common in FD than in OF [2,8-10]. GNAS (guanine nucleotide-binding protein $/ \alpha$-subunit) mutations that induce the activation of G-protein $\alpha$-subunit participate in the pathogenesis of fibrous dysplasia. There is a wellestablished association between fibrous dysplasia and post-zygotic activating mutations of the GNAS gene [11]. In a recent review by our group that updated the GNAS genetic mutation rate of in fibrous dysplasia was up to $86 \%(264 / 307)$, while no mutation was found in patients diagnosed with ossifying fibroma [9]. GNAS mutation detection may be helpful in differentiating fibrous dysplasia from other fibro-osseous lesions.

Hyperparathyroidism-jaw tumour syndrome (HPT-JT) is an autosomal dominant, multiple neoplastic syndrome primarily characterized by hyperparathyroidism caused by a parathyroid adenoma or adenocarcinoma [12,13]. Kidney lesions may also occur in HPT-JT, including bilateral cysts, renal hamartomas, or Wilms tumours. Benign and malignant uterine tumours are apparently common in women diagnosed with HPT-JT syndrome, including adenomyosis, adenofibroma, endometrial hyperplasia, leiomyoma, and adenosarcoma [14,15]. Recently, the candidate tumor suppressor gene HRPT2 was identified in chromosome 1q24-q32, enconding a novel protein of 531 amionacids named parafibromin [16]. Some studies showed that alterations in HRPT2 gene are related with HPT-JT and sporadic carcinoma and adenomas of parathyroid $[9,17]$ Alterations in the tumor suppressor gene HPRT2 in ossifying fibroma have recently been reported. Direct sequencing of the HPRT2 revealed mutations in two out of the four cases of ossifying fibroma. However, one of the two mutational cases is HPT-JT syndrome because of the increased PTH level [18]. These findings indicate that the HPRT2 mutation is not common in the development of sporadic ossifying fibroma, and therefore may not be used as a marker for diagnosis [5]. So when the HRPT2 gene revealed mutations, the HPT-JT syndrome should be noticed. About $30-40 \%$ of individuals diagnosed with HPT-JT may also develop single or multiple OFs, which are distinct from the "brown" tumours associated with severe hyperparathyroidism $[16,19,20]$. Multiple OFs in patients diagnosed with HPT-JT have been reported, but the ratio remains unknown. Typically, OFs are encountered as solitary lesions in patients with no family history. Multiple ossifying fibromas are rare, and only a few cases have been reported. Here we report two cases of sporadic multiple OFs with an emphasis on differential diagnosis between FD and HPT-JT related OFs.

\section{Materials and methods}

Cases diagnosed as OF during 1949-2013 were retrieved from the medical records of the Department of Oral Pathology, Peking University School of Stomatology. The study protocol was approved by the Ethical Committee for Human Experiments of Peking University School of Stomatology (IRB00001052-11041). Standard haematoxylin and eosin stained sections were reviewed, and the lesions were reclassified according to the WHO histological classification of odontogenic tumours [2]. Two cases of multiple OFs among 102 total confirmed OF cases were identified. Clinical data including age, sex, anatomic site, duration, radiographic features, clinical impression, treatment, and available follow-up data were reported. Mutational analysis of GNAS at the Arg201 and Gln227 codons and screening of all HRPT2 exons were performed on the tissue samples of the 2 cases using direct sequencing. In addition, multiple OFs and HPTJT related OF cases previously reported in the literatures were reviewed.

\section{Case presentation \\ Case 1}

The patient was a 19-year-old female, with a chief complaint of a slowly progressive, non-painful growth at the left mandible. Four years previously, maxillary surgery was performed at a local hospital on a lesion diagnosed as an ossifying fibroma. There was no specified anamnesis or family history of neoplasia. On present examination, clinicians observed a mild facial asymmetry with a hard swelling in the left mandible. The tumour was covered by normal intact alveolar mucosa. Panoramic radiography showed two well-demarcated bilateral radio lucencies in the mandible. The left premolars were displaced slightly due to extrusion, and the roots of two premolars were resorbed (Figure 1A). Biochemistry blood tests showed an elevated alkaline phosphatase of $278 \mathrm{IU} / \mathrm{L}$ (normal range 30-110 IU/L), but serum calcium and phosphorus were normal. PTH was not tested in this patient. The lesions were enucleated and easily from the surrounding bone. Histologically, the lesions demonstrated interlacing bundles of collagen fibres and cells associated with variablesized calcified tissue deposits (Figure 1B-C). The combination of histopathologic, radiographic, and clinical features 

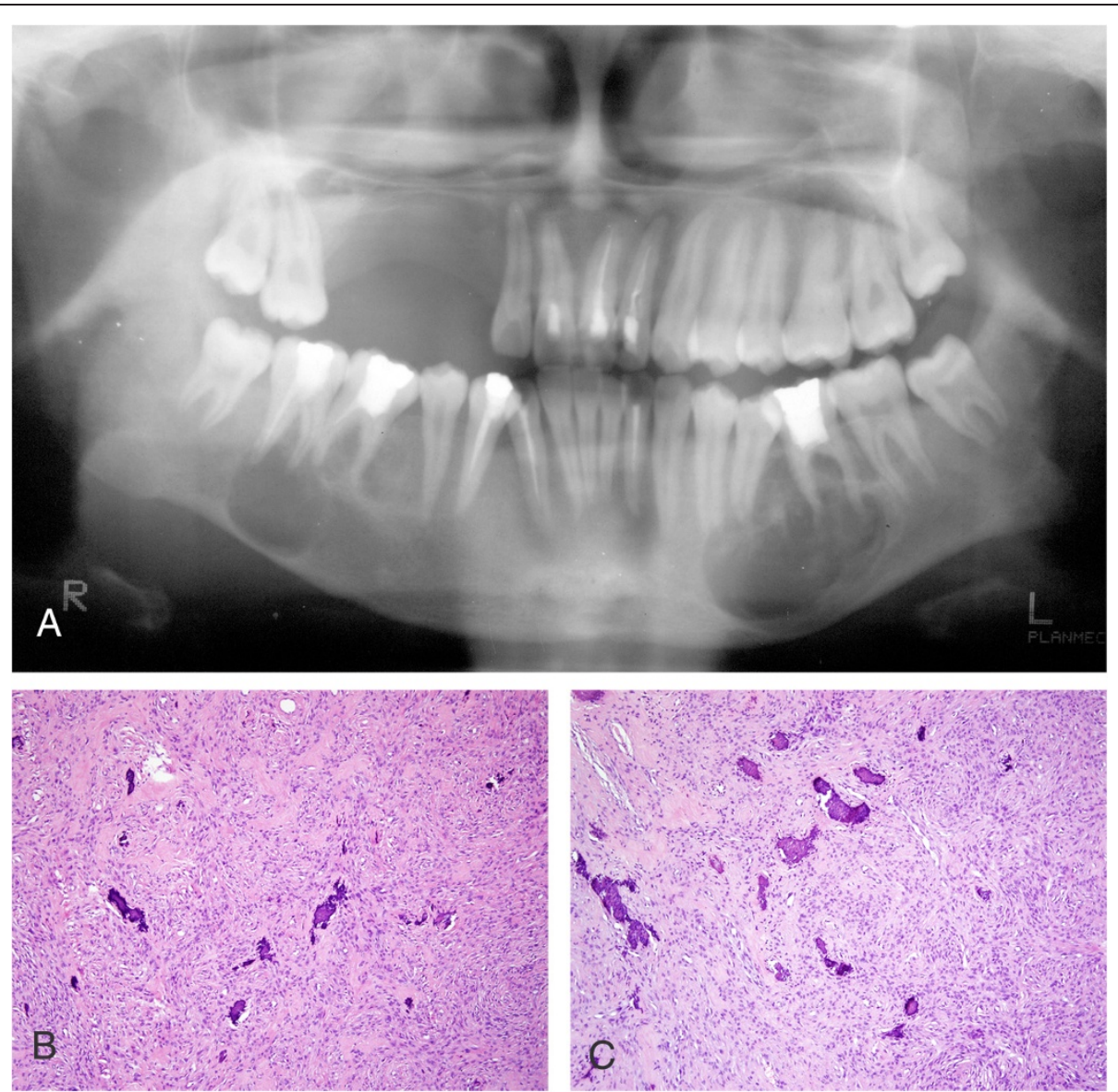

Figure 1 Radiographic and histopathologic features of Case 1. (A) Panoramic radiograph showing two well-demarcated radiolucencies bilaterally in the mandible. The right premolars were extruded and displaced, and the roots of two premolars were resorbed. (B-C) Haematoxylin and eosin stain (100x) showing interlacing bundles of collagen fibres and spindle cells associated with variably sized calcified tissue deposits.

supported a diagnosis of sporadic multiple conventional ossifying fibroma. Mutational analysis of GNAS and HRPT2 revealed no genetic abnormality in the lesion tissue samples. The lesions recurred one year after the first surgery, but the patient refused further treatment.

\section{Case 2}

A 6-year-old boy had synchronous lesions involving both the maxilla and mandible. His parents noticed the lesions 2 months prior to evaluation. The patient did not have any familial history of jaw disease. On examination, the lesions were firm and non-fluctuant, and bilateral mandibular buccal bone expansion was found extending from the deciduous canine to the deciduous molar. The overlying mucosa was intact. Panoramic radiography revealed a large lesion extending from the right ascending mandibular ramus to the left ascending mandibular ramus. The lesion consisted of a central heterogeneous mineralization and a thin marginal radiolucent area with a well-demarcated sclerotic border. Several tooth germs were displaced, and roots of multiple primary teeth were resorbed. The permanent molar teeth were significantly displaced, particularly the second molar, which was displaced into the ascending ramus (Figure 2A). A CT scan confirmed thinned bony cortex of the inferior mandibular border and alveolar bone expansion near the mixed radiopaque mass (Figure 2B). A displaced tooth germ grew into the maxillary sinus (Figure 2C). Blood tests (serum calcium, phosphorus, alkaline phosphatase, and PTH) were within normal limits. Incisional biopsies were performed in the mandibular and the maxillary lesions, and both specimens showed a similar histopathologic pattern. The lesions were mainly composed of fibrous tissue rich in fibroblasts with spherical calcifications. The mandibular lesion showed scarce areas of small spherical calcifications (Figure 2E); by contrast, the maxillary specimen exhibited a larger amount of these calcified structures (Figure 2F). The combination of histopathologic, radiographic, and clinical features supported a diagnosis of multiple conventional ossifying fibroma. Mutational analysis of GNAS and HRPT2 revealed no genetic abnormality in the lesions. Because of the patient's young age, the large size of the 


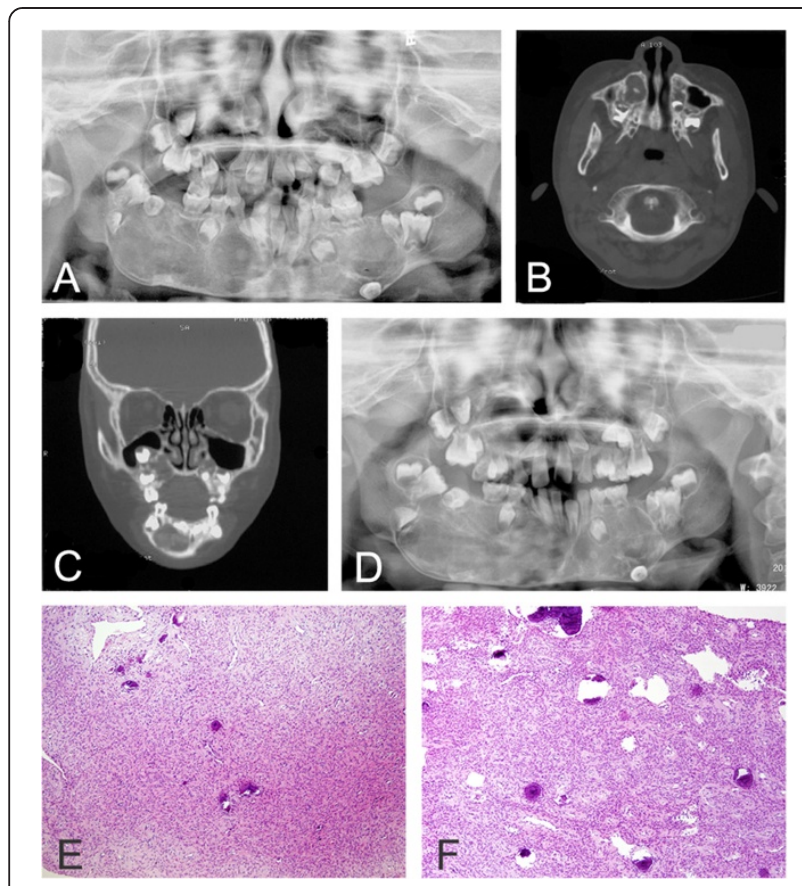

Figure 2 Radiographic and histopathologic features of Case 2.

(A) Panoramic radiograph showing well-demarcated mixeddensity lesions surrounded by sclerotic border involving four quarters of jaws. (B-C) CT scan demonstrating expansive lesions involving in the maxilla and mandible. (D) After 1 year, the lesions are visibly enlarged. (E) Haematoxylin and eosin stain (100x) of the mandibular lesion showing scarce areas of small spherical calcifications in dense fibroblasts. (F) Haematoxylin and eosin stain (100x) showing a similar maxillary lesion of densely packed fibroblasts and calcified structures.

lesions, and the involvement of all four jaw quadrants, treatment was delayed, and the patient was closely followed up for 1 year (Figure 2D).

\section{Literature review of sporadic multiple ossifying fibroma}

Based on a review of the literatures since 1968, together with the present two cases, 18 cases (16 previously reported cases [21-23]) of sporadic multiple ossifying fibroma were collected and summarized in Table 1 . There were $13(72.2 \%)$ female and $5(27.8 \%)$ male patients, and the mean age of the patients at initial diagnosis was 28.6 years old (range 6-55 years old). Bone swelling or expansion was the typical clinical sign and occurred in all patients. Two (11.1\%) cases were found only in the mandible, and $4(22.2 \%)$ cases were found only in the maxilla. Twelve $(68.8 \%)$ cases were found in both the maxilla and mandible. Radiographic findings included unilocular and multilocular patterns demonstrating varying degrees of radiopacity in 5 cases (27.8\%); radiolucencies with well-circumscribed borders were also found, and in 13 cases (72.2\%), mixed density intralesional calcification was observed. Among the 14 cases providing therapeutic information, enucleation was the primary treatment in 11 cases, and recurrence was documented in 3 cases (3/14) after 6 months, 1 year, and 2 years, respectively. Extended resection with an interpositional bone graft/titanium was performed in 2 cases, and no recurrence was reported. Treatment in case 2 was delayed because of the patient's young age, and the lesion was closely monitored during follow-up. In the previous 16 multiform OF cases, only 5 cases reported the serum calcium and phosphorus, and only 2 cases had special focus on the serum PTH.

\section{Literature review of HPT-JT related OF}

In total, 24 cases of HPT-JT related ossifying fibroma were reviewed and are summarized in Table 2 [12,15,24-37]. Of the 20 cases providing patient age and gender information, 6 patients were female, and 14 were male. The mean age at initial diagnosis was 23.8 years old (range 13 years to 54 years). Sixteen $(66.7 \%)$ patients were diagnosed with a single lesion, and 8 patients (33.3\%) were diagnosed with multiple jaw lesions. Among the 16 cases of unilocular lesions, 12 cases were located in the mandible, and 4 were in the maxilla; of the 8 multilocular cases, 2 were found only in the mandible, 1 case was only in the maxilla, and 5 cases were found in both the maxilla and the mandible.

\section{Discussion}

The ratio of multiple lesions OF cases to all OF cases is unclear, but we found only 2 cases in 102 case reviews (2.0\%). Only 16 known cases of multiple ossifying fibroma have been reported (Table 1) [21-23,38-50]. Although the patients were young in our two reported cases, the cases are not considered juvenile ossifying fibromas (not psammomatoid or trabecular type) because of the histologic features. The etiology and pathogenesis for both solitary and multiple OF remain unknown. However, both forms of OF present very similar clinical, radiologic, and histopathologic features, suggesting that they are different clinical presentations of the same disease [48].

According to the latest WHO classification, ossifying fibroma and fibrous dysplasia can be distinguished in the following manner. Radiologically, ossifying fibroma is a well-demarcated lesion and does not merge with the surrounding bone. Histopathologically, normal bone is replaced by fibroblastic stoma with calcifications and osteoblastic rimming observed [2,51]. However, the histopathologic characteristics of the two diseases may overlap, making diagnosis difficult. Detection of GNAS mutations is one valuable diagnostic adjunct [9]. Somatic mutations at the $\mathrm{Arg}^{201}$ and $\mathrm{Gln}^{227}$ codon of Gs $\alpha$ have been identified in many fibrous dysplastic lesions, but are absent in ossifying fibromas, which points to a possible role for mutational analysis in differentiating these two conditions $[5,9,52,53]$. In the present two cases, the 
Table 1 Summary of total 18 cases of sporadic multiple ossifying fibromas

\begin{tabular}{|c|c|c|c|c|c|c|c|c|c|c|}
\hline No. & Reference & $\begin{array}{l}\text { Gender/ } \\
\text { on set } \\
\text { age (year) }\end{array}$ & Site $^{\mathrm{b}}$ & Image features $^{c}$ & $\begin{array}{l}\text { Displacement } \\
\text { of the teeth// }^{\text {d }} \\
\text { root Resorption }^{\text {d }}\end{array}$ & Biochemistry test $^{\mathrm{e}}$ & Treatment & Follow-up & $\begin{array}{l}\text { GNAS } \\
\text { mutation } \\
\text { analysis }\end{array}$ & $\begin{array}{l}\text { HRPT2 } \\
\text { mutation } \\
\text { analysis }\end{array}$ \\
\hline 1 & $\begin{array}{l}\text { Bradley } \\
\text { and Leake } \\
\text { [38], } 1968\end{array}$ & $F / 6$ & $\begin{array}{l}\text { Les. 1: rught maxilla } \\
\text { Les. 2: right angle } \\
\text { of the mandible }\end{array}$ & P.R.: multicystic Lesions & Yes/N.S. & N.S. & $\begin{array}{l}\text { Right maxilla: } \\
\text { enucleation and } \\
\text { curettage right } \\
\text { mandible: scheduled } \\
\text { for removal }\end{array}$ & N.S. & N.S. & N.S. \\
\hline 2 & $\begin{array}{l}\text { Takeda and } \\
\text { Fujioka } \\
\text { [39], } 1987\end{array}$ & $M / 55$ & $\begin{array}{l}\text { Les. 1: left maxilla } \\
\text { Les. 2: right maxilla }\end{array}$ & $\begin{array}{l}\text { P.R: well-circumscribed lesions } \\
\text { showed radiolucent areas } \\
\text { mixed with radiopaque areas }\end{array}$ & N.S. & N.S. & N.S. & $\begin{array}{l}\text { Patient refused } \\
\text { treatment }\end{array}$ & N.S. & N.S. \\
\hline 3 & $\begin{array}{l}\text { Hauser et al } \\
\text { [40], } 1989\end{array}$ & $M / 35$ & $\begin{array}{l}\text { Les. 1: right } \\
\text { maxillary sinus } \\
\text { Les. 2: left maxillary } \\
\text { sinus }\end{array}$ & $\begin{array}{l}\text { P.R.: well-circumscribed mixed } \\
\text { radiolucent/radiopaque lesions } \\
\text { CT: well-circumscribed lesion with } \\
\text { calcified masses }\end{array}$ & No/N.S. & N.S. & $\begin{array}{l}\text { Right maxillary sinus: } \\
\text { enucleation left } \\
\text { maxillary sinus: partial } \\
\text { hemimaxillectomy }\end{array}$ & N.S. & N.S. & N.S. \\
\hline 4 & $\begin{array}{l}\text { Yih et al [41], } \\
1989\end{array}$ & $F / 31$ & $\begin{array}{l}\text { Les. 1: left mandible } \\
\text { Les. 2: right maxilla } \\
\text { Les. 3: left mandible } \\
\text { (2 years later) }\end{array}$ & $\begin{array}{l}\text { P.R.: well circumscribed unilocular } \\
\text { radiolucency }\end{array}$ & N.S. & $\begin{array}{l}\text { ALP: } 218 \mathrm{IU} / \mathrm{L} \uparrow \\
\text { Ca }: \text { normal limits } \\
\text { P: normal limits }\end{array}$ & $\begin{array}{l}\text { Left mandibular body } \\
\text { and right maxilla: } \\
\text { enucleation }\end{array}$ & $\begin{array}{l}\text { Recurrence of } \\
\text { the left mandible } \\
\text { after } 2 \text { y later }\end{array}$ & N.S. & N.S. \\
\hline 5 & $\begin{array}{l}\text { Khanna and } \\
\text { Andrade } \\
\text { [42], } 1992\end{array}$ & $M / 33$ & $\begin{array}{l}\text { Les. 1: right maxilla } \\
\text { Les. 2: left mandible }\end{array}$ & $\begin{array}{l}\text { P.R.: large lesions contained } \\
\text { diffused calcifications }\end{array}$ & N.S. & $\begin{array}{l}\text { ALP: normal limits } \\
\text { Ca: normal limits }\end{array}$ & $\begin{array}{l}\text { Both of the two } \\
\text { lesions: enucleation }\end{array}$ & Lost for follow-up & N.S. & N.S. \\
\hline 6 & $\begin{array}{l}\text { Hwang et al } \\
{[43], 2001}\end{array}$ & $F / 25$ & $\begin{array}{l}\text { Les. 1: right } \\
\text { mandible } \\
\text { Les. 2: left maxilla } \\
\text { Les. 3: left mandibuar body } \\
\text { Les. 4: left maxilla } \\
\text { Les. 5: right maxilla }\end{array}$ & $\begin{array}{l}\text { P.R.: large calcified mass } \\
\text { surrounded by a radiolucent halo } \\
\text { zone with corticated margin }\end{array}$ & Yes/yes & N.S. & $\begin{array}{l}\text { Right mandible: partial } \\
\text { hemimandibulectomy } \\
\text { right maxilla: } \\
\text { hemimaxillectomy }\end{array}$ & $\begin{array}{l}\text { Initially refused } \\
\text { treatment; } 3 \text { y } \\
\text { later, surgical } \\
\text { remission of the } \\
\text { lesions was } \\
\text { undertaken }\end{array}$ & N.S. & N.S. \\
\hline 7 & $\begin{array}{l}\text { Bertolini et al } \\
{[44], 2002}\end{array}$ & $F / 37$ & $\begin{array}{l}\text { Les. 1: left maxilla. } \\
\text { and hard palate } \\
\text { Les. 2: right } \\
\text { mandible } \\
\text { Les. 3: left mandible }\end{array}$ & $\begin{array}{l}\text { P.R.: large radiolucency lesions with } \\
\text { interspersed calcifications } \\
C \text { : revealed fibrous calcified masses } \\
\text { that involved the left maxilla and } \\
\text { the right and left mandibular body }\end{array}$ & No/no & N.S. & $\begin{array}{l}\text { Right mandible: partial } \\
\text { mandibulectomy Left } \\
\text { mandible: curettage } \\
\text { Left maxilla: intraoral } \\
\text { surgical removal }\end{array}$ & $\begin{array}{l}\text { Mandible: no } \\
\text { recurrencey after } \\
2 \text { y Maxilla.: no } \\
\text { recurrence after } 1 \text { y }\end{array}$ & N.S. & N.S. \\
\hline 8 & $\begin{array}{l}\text { Barberi et al } \\
{[45], 2003}\end{array}$ & $F / 53$ & $\begin{array}{l}\text { Les. 1: left } \\
\text { infraorbital region } \\
\text { Les. 2: right hard } \\
\text { palate }\end{array}$ & $\begin{array}{l}\text { P.R.: showed partial opacification } \\
\text { of left maxillary sinus } \\
\text { CT: two different multilocular, } \\
\text { inhomogeneously hypodense } \\
\text { entities walled in an irregularly } \\
\text { thick sclerotic border }\end{array}$ & No /no & N.S. & N.S. & N.S. & N.S. & N.S. \\
\hline 9 & $\begin{array}{l}\text { Stergiou et al } \\
{[46], 2007}\end{array}$ & $F / 36$ & $\begin{array}{l}\text { Les. 1: left mandible } \\
\text { Les. 2: right mandible } \\
\text { Les. 3: left maxilla }\end{array}$ & $\begin{array}{l}\text { P.R.: well circumscribed unilocular } \\
\text { radiolucency containing diffuse } \\
\text { calcifications } \\
\text { CT: well demarcated lesions, } \\
\text { low density and scattered } \\
\text { calcifications }\end{array}$ & N.S. & N.S. & $\begin{array}{l}\text { Enucleation and } \\
\text { curettage }\end{array}$ & $\begin{array}{l}\text { No recurrence after } \\
6 \text { months }\end{array}$ & N.S. & N.S. \\
\hline 10 & $\begin{array}{l}\text { Chindia et al } \\
{[47], 2008}\end{array}$ & $F / 27$ & $\begin{array}{l}\text { Les. 1: right angle } \\
\text { and body of the } \\
\text { mandible } \\
\text { Les. 2: left maxilla }\end{array}$ & $\begin{array}{l}\text { P.R.: mandibular lesion was } \\
\text { corticated and maxillary } \\
\text { lesion was less well defined } \\
\text { with almost complete obliteration } \\
\text { of the maxillary sinus }\end{array}$ & N.S. & N.S. & $\begin{array}{l}\text { Both of the lesions: } \\
\text { enucleation }\end{array}$ & $\begin{array}{l}\text { Recurrence after } \\
6 \text { months (mandible) }\end{array}$ & N.S. & N.S. \\
\hline
\end{tabular}


Table 1 Summary of total 18 cases of sporadic multiple ossifying fibromas (Continued)

\begin{tabular}{|c|c|c|c|c|c|c|c|c|c|c|}
\hline 11 & $\begin{array}{l}\text { Ribeiro et al } \\
{[48], 2011}\end{array}$ & $F / 35$ & $\begin{array}{l}\text { Les. 1: left mandible } \\
\text { Les. 2: right mandible }\end{array}$ & $\begin{array}{l}\text { P.R.: large radiolucency } \\
\text { surrounded by a radiopaque } \\
\text { halo in the left and right mandible } \\
\mathrm{CT} \text { : unilocular and hypodense image }\end{array}$ & Yes/yes & $\begin{array}{l}\text { Ca: } 9.73 \mathrm{mg} / \mathrm{dl} \\
\text { P: } 4.2 \mathrm{mg} / \mathrm{dL} \\
\text { PTH: } 56.34 \mathrm{pg} / \mathrm{mL}\end{array}$ & $\begin{array}{l}\text { Both lesions: } \\
\text { enucleation }\end{array}$ & $\begin{array}{l}\text { No recurrence } \\
\text { after } 3 \text { y }\end{array}$ & N.S. & N.S. \\
\hline 12 & $\begin{array}{l}\text { Agarwal et al } \\
\text { [50], } 2012\end{array}$ & $F / 20$ & $\begin{array}{l}\text { Les. 1: left posterior } \\
\text { maxilla } \\
\text { Les. 2: right posterior } \\
\text { mandible }\end{array}$ & $\begin{array}{l}\text { P.R.: maxillary and mandibular } \\
\text { lesion was well-defined with a } \\
\text { radiolucent rim and sclerotic border } \\
\text { CT: hyperattenuated } \\
\text { masses in left maxillary and } \\
\text { right mandibular alveolar ridges }\end{array}$ & Yes/no & N.S. & N.S. & $\begin{array}{l}\text { Take an operation } \\
\text { fifteen years ago } \\
\text { of maxilla }\end{array}$ & N.S. & N.S. \\
\hline 13 & $\begin{array}{l}\text { Popli et al } \\
\text { [21], } 2012\end{array}$ & $F / 19$ & $\begin{array}{l}\text { Les. 1: left maxilla } \\
\text { Les. 2: right mandible }\end{array}$ & $\begin{array}{l}\text { P.R.: well-defined mixed radiolucent } \\
\text { and radiopaque lesions } \\
\text { CT: mixed-density, expansile } \\
\text { lesions present at the alveolar process } \\
\text { of both the maxilla walled by ir } \\
\text { regularly thick sclerotic border. }\end{array}$ & Yes/yes & $\begin{array}{l}\text { No sign of } \\
\text { hyperparathyroidism }\end{array}$ & Enucleation & $\begin{array}{l}\text { No recurrence } \\
\text { after } 2 \text { y }\end{array}$ & N.S. & N.S. \\
\hline 14 & $\begin{array}{l}\text { Akcam et al } \\
{[49], 2012}\end{array}$ & $M / 20$ & $\begin{array}{l}\text { Les. 1: left maxilla } \\
\text { Les. 2: left mandible }\end{array}$ & $\begin{array}{l}\text { P.R.: well defined,multilocular } \\
\text { radiolucent lesion of the left } \\
\text { mandible unilocular radiolucent } \\
\text { lesion in the left maxilla } \\
\text { CT: extensivehypodense } \\
\text { lesions with cortical expansion }\end{array}$ & Yes/no & $\begin{array}{l}\text { Ca, P, PTH within } \\
\text { normal limits }\end{array}$ & Enucleation & $\begin{array}{l}\text { No recurrence after } \\
8 \text { months }\end{array}$ & N.S. & N.S. \\
\hline 15 & $\begin{array}{l}\text { Kiran Desai } \\
\text { et al [22], } 2013\end{array}$ & $F / 18$ & $\begin{array}{l}\text { Les. 1: right maxilla } \\
\text { Les. 2: right mandible }\end{array}$ & $\begin{array}{l}C \text { T: large well-defined expansile lesion, } \\
\text { heterogeneously hyper dense, multiple } \\
\text { internal punctuate calcifications }\end{array}$ & Yes/N.S. & $\begin{array}{l}\text { Blood calcium levels } \\
\text { within normal limits, } \\
\text { no sign of } \\
\text { hyperparathyroidism }\end{array}$ & Enucleation & $\begin{array}{l}\text { No recurrence after } \\
2 \text { years }\end{array}$ & N.S. & N.S. \\
\hline 16 & $\begin{array}{l}\text { Ponniah et al } \\
{[23], 2013}\end{array}$ & $F / 45$ & $\begin{array}{l}\text { mutiple lesions from the left } \\
\text { mandible to the right } \\
\text { mandible }\end{array}$ & $\begin{array}{l}\text { P.R.: multilocular radiolucent lesion } \\
\text { CT: osteolytic, soft-tissue density } \\
\text { lesion with thinning and erosion of } \\
\text { the buccal cortex in the anterior } \\
\text { region of the mandible }\end{array}$ & Yes/yes & N.S. & Enucleation & $\begin{array}{l}\text { No recurrence after } \\
5 \text { months }\end{array}$ & N.S. & N.S. \\
\hline 17 & Present case 1 & $F / 15$ & $\begin{array}{l}\text { Les.1: right maxilla } \\
\text { Les. 2, 3: bilateral mandible }\end{array}$ & $\begin{array}{l}\text { P.R.: well demarcated radiolucency } \\
\text { in the bilateral mandible }\end{array}$ & Yes/yes & $\begin{array}{l}\text { Ca: } 2.7 \mathrm{mmol} / \mathrm{L} \\
\text { P: } 0.77 \mathrm{mmol} / \mathrm{L} \downarrow \\
\text { ALP: } 278 \mathrm{IU} / \mathrm{L} \uparrow \\
\text { PTH not find to text }\end{array}$ & Enucleation & $\begin{array}{l}\text { Recurrence after } \\
1 \text { year }\end{array}$ & No & No \\
\hline 18 & Present case 2 & M/6 & $\begin{array}{l}\text { Les. 1: right maxilla } \\
\text { Les. 2: left maxilla } \\
\text { Les. 3: right mandible } \\
\text { Les. 4: left mandible }\end{array}$ & $\begin{array}{l}\text { P.R.:central inhomogeneous } \\
\text { mineralizationin thin marginal } \\
\text { radiolucent area with a well } \\
\text { demarcated sclerotic border } \\
\text { CT: mixed radiopaque image }\end{array}$ & Yes/yes & $\begin{array}{l}\text { Ca: } 2.63 \mathrm{mmol} / \mathrm{L} \\
\text { P: } 1.58 \mathrm{mmol} / \mathrm{L} \\
\text { ALP: } 62 \mathrm{IU} / \mathrm{L} \text { PTH } \\
9.12 \mathrm{pg} / \mathrm{mL}\end{array}$ & $\begin{array}{l}\text { Incisional biopsies the } \\
\text { treatment delayed } \\
\text { because of the young } \\
\text { age }\end{array}$ & $\begin{array}{l}\text { After } 1 \text { year, the } \\
\text { lesions enlarged } \\
\text { obviously }\end{array}$ & No & No \\
\hline
\end{tabular}

\section{${ }^{\mathrm{a}} \mathrm{F}=$ female; $\mathrm{M}=$ Male}

bes. $=$ lesion.

${ }^{\mathrm{C} P . R .}=$ panoramic radiograph; $\mathrm{CT}=$ Computerized Tomography

${ }^{\mathrm{d} N . S .}=$ not stated

${ }^{\mathrm{e}} \mathrm{ALP}=$ Alkaline phosphatase; $\mathrm{Ca}=$ Serum calcium; $\mathrm{P}=$ Phosphate. 
Table 2 Cases of ossifying fiboma affected with HPT-JT in the literature

\begin{tabular}{|c|c|c|c|c|}
\hline Number & Author & Age/gender ${ }^{a}$ & Single/multiple & Location \\
\hline 1 & Kutcher [24] & $22 / \mathrm{M}$ & Single & The right posterior mandible \\
\hline 2 & lacobone [25] & $26 / F$ & Single & Left mandible ramus \\
\hline 3 & Yamashita [15] & $18 / \mathrm{M}$ & Single & Right maxilla \\
\hline 4 & Raue [26] & $29 / M$ & Single & Mandible \\
\hline 5 & Moon [27] & 18/M & Single & Left mandible \\
\hline 6 & & $17 / F$ & Single & The right mandible \\
\hline 7 & Teh [28] & $26 / M$ & Single & Left maxilla \\
\hline 8 & Mallette [29] & 36/N.S.* & Single & Maxilla \\
\hline 9 & Rekik [30] & $23 / \mathrm{F}$ & Single & The right body of the mandible \\
\hline 10 & Dinnen [31] & $18 / \mathrm{M}$ & Single & The right molar region of the mandible \\
\hline 11 & Cavaco [32] & $18 / \mathrm{M}$ & Single & Maxilla \\
\hline 12 & & $31 / \mathrm{M}$ & Single & Mandible \\
\hline 13 & & $23 / \mathrm{M}$ & Single & Mandible \\
\hline 14 & & $21 / F$ & Single & Mandible \\
\hline 15 & Wamakulasuriya [36] & $37 / M$ & Single & The left mandible \\
\hline 16 & & $43 / \mathrm{M}$ & Single & The left mandible \\
\hline \multirow[t]{2}{*}{17} & Teh [28] & $54 / \mathrm{M}$ & Multiple & Lesion 1: mandible \\
\hline & & & & Lesion 2: maxilla \\
\hline \multirow[t]{2}{*}{18} & Mallette [29] & $17 /$ N.S.* & multiple & Lesion 1: mandible \\
\hline & & & & Lesion 2: hard palate \\
\hline \multirow[t]{4}{*}{19} & Schmidt [33] & $37 \mathrm{M}$ & Multiple & Lesion 1: right maxillary canine and premolar areas \\
\hline & & & & Lesion 2: left maxillary canine and premolar areas \\
\hline & & & & Lesion 3: left mandible \\
\hline & & & & Lesion 4: right mandible \\
\hline \multirow[t]{2}{*}{20} & Szabo [34] & $22 / \mathrm{M}$ & Multiple & Lesion 1: right maxilla \\
\hline & & & & Lesion 2: in the right mandible \\
\hline \multirow[t]{2}{*}{21} & Howell [35] & $16 / \mathrm{M}$ & Multiple & Lesion 1: right mandible \\
\hline & & & & Lesion 2: right mandible \\
\hline \multirow[t]{2}{*}{22} & Aldred [12] & $22 / \mathrm{M}$ & Multiple & Lesion 1 the right mandible \\
\hline & & & & Lesion 2: the left mandible \\
\hline \multirow[t]{3}{*}{23} & Fujikawa [37] & $22 / F$ & Multiple & Lesion 1: left maxilla \\
\hline & & & & Lesion 2:left mandible \\
\hline & & & & Lesion 3: right mandible \\
\hline \multirow[t]{2}{*}{24} & Cavaco [32] & $13 / \mathrm{F}$ & Multiple & Lesion1: maxilla \\
\hline & & & & Lesion 2: mandible \\
\hline
\end{tabular}

lesions had a demarcated border radiographically, as well as tooth displacement and root resorption. Genetic screening of the GNAS gene at Arg201 and Gln227 codon did not show any anomalies, which confirmed the diagnosis of OF.

HPT-JT, considered a rare variant of familial HPT, was first described in 1990 [14]. Hypercalcemia and high PTH levels are associated with HPT-JT, andossifying fibromas reportedly occur in $25-50 \%$ of HPT-JT cases
$[16,54]$. We reviewed the literature reporting cases of HPT-JT with jaw ossifying fibromas (Table 2). In the 24 identified cases, $16(66.7 \%)$ cases were solitary lesions, and $8(33.3 \%)$ cases were multiple lesions. Thus, sporadic multiple ossifying fibroma must be distinguished from cases of HPT-JT. HPT-JT has been classically described as a more aggressive disease characterized by multiple organ involvement (45\%-75\%), increased risk of persistence and recurrences $(20 \%-50 \%)$, and parathyroid carcinoma 
(10\%-40\%) [25]. The suggested therapeutic approach is parathyroid gland resection, which prevents parathyroid carcinoma recurrence $[55,56]$. Differential diagnosis of ossifying fibroma associated with HPT-JT from sporadic ossifying fibroma is important for treatment and prognosis. In the cases reviewed, the serum calcium and PTH levels were normal in case 2, allowing us to exclude the association with HPT-JT. PTH was not measured in case 1 , but the patient had a normal calcium level and no family history of HPT-JT. Therefore, both cases were excluded from an association with HPT-JT. In the previously reported 16 multiform OF cases, only 5 cases had reported serum levels of calcium and phosphorus, and only 2 cases reported the serum PTH level; therefore, an association with HPTJT cannot be ruled out. HRPT2 genetic mutations are associated with the hereditary pathogenesis of HPT-JT syndrome [16]. Thus, HRPT2 genetic evaluation was conducted in the present two cases, and showed no mutational alternation. Based on the clinical and molecular findings, these two cases should be considered sporadic, non HPT-JT cases.

There is another heterogeneous group of reactive BFOL lesions, known as osseous dysplasia (OD); the lesions are associated with the tooth apex and may be unifocal or florid, involving most of the mandible [57]. The 2005 WHO classification divides ODs into focal, periapical, and florid OD, and familial gigantiform cementoma [2]. Differential diagnosis between ossifying fibroma and osseous dysplasia is important. Radiographically, OD is diffuse and amorphous, with mixed radiopaque to radiolucent lesions. Histologic features include a cellular connective tissue stroma punctuated by irregular osseous and/or cementumlike calcifications [58]. According to the authors [58], the criteria distinguishing OD from other fibro-osseous lesions are: (1) a histologic pattern consisting of cellular mesenchymal tissue with intermixed calcifications; (2) radiolucent and/or radiopaque lesions in the jaws; (3) surgically, an easily fragmented, haemorrhagic, gritty mass difficult to remove from the bone; and (4) gross observations of multiple haemorrhagic fragments of variable consistency. Osseous dysplasia is thought to be non-neoplastic and originating from the periodontal ligament [3]. Further surgical intervention is not necessary for small lesions, but periodic follow-up is recommended. Most OFs were not associated with the tooth apex, but often caused divergence or displacement of involved teeth [59]. Another rare hereditary condition with radiographic and histologic features similar to florid OD is familial gigantiform cementoma, which tends to occur in early childhood or teenhood [10]. Exuberant fibro-osseous lesions occurring in multiple jaw quadrants were designated as gigantiform cementomas or familial multiple cementomas in the first edition of the WHO's Histological Typing of Odontogenic Tumours,
Jaw cysts, and Allied Lesions [60]. These lesions have also been reported as familial florid cemento-osseous dysplasia [61] and familial florid osseous dysplasia [62]. Although cases with a familial pattern are noted in a few publications, sporadic cases without a family history have also been reported [63]. Some authors suggested that these cases were classified primarily as "ossifying fibroma" rather than "gigantiform cementoma" [64]. Compared to the multiple ossifying fibroma, the clinicoradiologic features are similar to those of florid osseous dysplasia: lesions surrounding the root; an outer layer of dense opacities, and multiquadrant, expansive, mixed radiolucent to opaque lesions crossing the jaw midlines. Microscopically dispersed throughout the lesions are ovoid, often laminated, variably sized psammomatoid calcifications. Many of these spheroidal calcifications are large, much larger than those observed in the psammomatoid variant of ossifying fibroma [1]. Under polarized light, Sharpy's fibres are seen projecting radially from these larger spheroidal deposits and resemble cementicles normally encountered in the periodontal ligament [1].

Fibro-osseous lesions of the jaw and face must be differentiated from other bone lesions that may mimic them histologically and radiographically. The most important lesions in differential diagnosis are osteoblastoma, adamantinoma and giant cell granuloma. Osteoblastoma is a benign radiolytic bone-forming neoplasm that is most common in the postcranial skeleton, particular the posterior elements of the spine, and it also may occur in the maxillofacial region [65]. Histologically, the central differentiating characteristic is the lack of cellular spindle cells in the stroma, which instead comprises loose vasculature with numerous prominent epithelioid-type osteoblasts [57]. Nawal Hammas' recent study shows that P63 may serve as a biomarker for the differential diagnosis between giant cell tumor of bone and other morphologically similar lesions, especially central giant cell granuloma since the latter does not express P63 [66]. Adamantinoma is a primary lowgrade, malignant bone tumor that is predominantly located in the mid-portion of the tibia. Histologically, classic adamantinoma is a biphasic tumor characterized by epithelial and osteofibrous components that may be intermingled with each other in various proportions and differentiating patterns [67]. Chondromyxoid fibromas are rare benign chondroid/myxoid matrix-producing tumors that occur in metaphyses of long tubular bones. Prior cytogenetic analyses have identified complex abnormalities involving chromosome 6 in the majority of cases and the cells can be positive for actin [68].

\section{Conclusion}

In conclusion, the suggested therapeutic approach for HPT-JT is parathyroid gland resection to prevent occurrence of the parathyroid carcinoma. Differential 
diagnosis of ossifying fibroma associated with HPT-JT and sporadic ossifying fibroma is important for treatment and prognosis. We presented 2 cases of multiple ossifying fibroma to illustrate to clinicians and radiologists that ossifying fibroma may have multiple forms and can be linked to hereditary syndromes. Genetic screening of GNAS could facilitate differential diagnosis of fibrous dysplasia at the molecular level. Furthermore, we strongly recommend that patients diagnosed with multiple or familial ossifying fibromas receive serum tests for $\mathrm{PTH}$ and mutation screening of HRPT2, which could exclude possible association with the HPT-JT syndrome.

\section{Consent}

Written informed consent was obtained from the patient (patient 1) and the patient's parent (patient 2) for publication of this Case Report and any accompanying images. A copy of the written consent is available for review by the Editor-in-Chief of this journal.

\section{Abbreviations}

BFOL: Benign fibro-osseous lesions; OF: Ossifying fibroma; FD: Fibrous dysplasia; OD: Osseous dysplasia; MFD: Monostotic fibrous dysplasia; PFD: Polyostotic fibrous dysplasia; HPT-JT: Hyperparathyroidism-jaw tumour syndrome; PTH: Parathyroid hormone.

\section{Competing interests}

The authors declare that they have no competing interests.

\section{Authors' contributions}

TTW and RZ participated in the histopathological evaluation, performed the literature review, acquired photomicrographs and drafted the manuscript. YC and QD established the diagnosis of the case described in figures and performed the radiological examination. LW and TJL conceived and designed the study, and revised the manuscript for important intellectual content. All authors read and approved the final manuscript.

\section{Authors' information}

Ting-ting Wang and Ran Zhang: co-first author.

\section{Acknowledgements}

This work was supported by Research Grants from the National Natural Science Foundation of China (81141092, 81030018 and 81302349). The authors also gratefully acknowledge the patients for their cooperation.

\section{Author details}

'Department of Oral Medicine, Hebei United University, School and Hospital of Stomatology, Tangshan, 82 South Construction Road, Hebei 063000, Lubei District, PR China. ${ }^{2}$ Department of Oral Pathology, Peking University School and Hospital of Stomatology, 22 South Zhongguancun Avenue, Haidian District, Beijing 100081, PR China. ${ }^{3}$ Central Laboratory, Peking University School and Hospital of Stomatology, Beijing, China. ${ }^{4}$ National Engineering Laboratory for Digital and Material Technology of Stomatology, Beijing, China.

Received: 30 December 2013 Accepted: 7 February 2014 Published: 28 March 2014

\section{References}

1. Eversole R, Su L, ElMofty S: Benign fibro-osseous lesions of the craniofacial complex: a review. Head Neck Pathol 2008, 2:177-202.

2. Barnes L, Eveson J, Reichart P, Sidransky D: World Health Organization Classification of Tumours: Pathology and Genetics of Head and Neck Tumours, Book World Health Organization Classification of Tumours: Pathology and Genetics of Head and Neck Tumours. Lyon: IARC Press; 2005.
3. Waldron CA: Fibro-osseous lesions of the jaws. J Oral Maxillofac Surg 1993, 51:828-835.

4. Chambers MS, Rassekn CH, Toth BB, Lemon JC, Hoffman RD: A maxillary fibro-osseous lesion: differential diagnosis and case report. Tex Dent $J$ 2002, 119:12-19.

5. Toyosawa S, Yuki M, Kishino M, Ogawa Y, Ueda T, Murakami S, Konishi E, lida S, Kogo M, Komori T, Tomita Y: Ossifying fibroma vs fibrous dysplasia of the jaw: molecular and immunological characterization. Modern Pathol 2007, 20:389-396.

6. Alawi F: Benign fibro-osseous diseases of the maxillofacial bones. A review and differential diagnosis. Am J Clin Pathol 2002, 118(Suppl):S50-S70.

7. Kusano T, Hirabayashi S, Eguchi T, Sugawara Y: Treatment strategies for fibrous dysplasia. J Craniofac Surg 2009, 20:768-770.

8. Slootweg PJ: Bone diseases of the jaws. Int J Dent 2010, 2010:702314.

9. Shi RR, Li XF, Zhang R, Chen Y, Li TJ: GNAS mutational analysis in differentiating fibrous dysplasia and ossifying fibroma of the jaw. Modern Pathol 2013, 26:1023-1031.

10. Brannon RB, Fowler CB: Benign fibro-osseous lesions: a review of current concepts. Adv Anat Pathol 2001, 8:126-143.

11. Kuznetsov SA, Cherman N, Riminucci M, Collins MT, Robey PG, Bianco P: Age-dependent demise of GNAS-mutated skeletal stem cells and "normalization" of fibrous dysplasia of bone. J Bone Miner Res 2008, 23:1731-1740.

12. Aldred MJ, Talacko AA, Savarirayan R, Murdolo V, Mills AE, Radden BG, Alimov A, Villablanca A, Larsson C: Dental findings in a family with hyperparathyroidismjaw tumor syndrome and a novel HRPT2 gene mutation. Oral Surg Oral Med Oral Pathol Oral Radiol Endod 2006, 101:212-218.

13. Cavaco BM, Barros L, Pannett AA, Ruas L, Carvalheiro M, Ruas MM, Krausz T, Santos MA, Sobrinho LG, Leite V, Thakker RV: The hyperparathyroidism-jaw tumour syndrome in a Portuguese kindred. QJM 2001, 94:213-222.

14. Jackson CE, Norum RA, Boyd SB, Talpos GB, Wilson SD, Taggart RT, Mallette LE: Hereditary hyperparathyroidism and multiple ossifying jaw fibromas: a clinically and genetically distinct syndrome. Surgery 1990, 108:1006-1012. discussion 1012-1003.

15. Yamashita Y, Akiyama T, Mizusawa N, Yoshimoto K, Goto M: A case of hyperparathyroidism-jaw tumour syndrome found in the treatment of an ossifying fibroma in the maxillary bone. Int J Oral Max Surg 2007, 36:365-369.

16. Carpten J, Robbins C, Villablanca A, Forsberg L, Presciuttini S, Bailey-Wilson J, Simonds W, Gillanders E, Kennedy A, Chen J: HRPT2, encoding parafibromin, is mutated in hyperparathyroidism-jaw tumor syndrome. Nat Gen 2002, 32:676-680.

17. Shattuck TM, Valimaki S, Obara T, Gaz RD, Clark OH, Shoback D, Wierman ME, Tojo K, Robbins CM, Carpten JD, Farnebo LO, Larsson C, Arnold, A: Somatic and germ-line mutations of the HRPT2 gene in sporadic parathyroid carcinoma. New Engl J Med 2003, 349:1722-1729.

18. Pimenta FJ, Gontijo Silveira LF, Tavares GC, Silva AC, Perdigao PF, Castro WH, Gomez MV, Teh BT, De Marco L, Gomez RS: HRPT2 gene alterations in ossifying fibroma of the jaws. Oral Oncol 2006, 42:735-739.

19. Haven CJ, Wong FK, van Dam EW, van der Luijt R, van Asperen C, Jansen J, Rosenberg C, de Wit M, Roijers J, Hoppener J: A genotypic and histopathological study of a large Dutch kindred with hyperparathyroidism-jaw tumor syndrome. J Clin Endocr Metab 2000, 85:1449-1454.

20. Hobbs MR, Pole AR, Pidwirny GN, Rosen IB, Zarbo RJ, Coon H, Heath H 3rd, Leppert M, Jackson CE: Hyperparathyroidism-jaw tumor syndrome: the HRPT2 locus is within a 0.7-cM region on chromosome 1q. Am J Hum genet 1999, 64:518-525.

21. Popli DB, Desai R, Bansal S, Andrade NN: Bilateral psammomatoid ossifying fibroma: a case report and review of the literature. J Oral Maxillofac Surg 2013, 71:714-720.

22. Desai K, Gupta K, Manjunatha BS, Palan S: Bimaxillary presentation of central ossifying fibroma: a unique aggressive entity. BMJ Case Rep 2013, 2013. doi:10.1136/bcr-2013-010124.

23. Ponniah I, Sethurajan SB, Rajiah D: A multilocular radiolucency with spindle cell proliferation in a case of ossifying fibroma: a potential pitfall. Dento Maxillo Facial Radiol 2012, 41:605-608.

24. Kutcher MR, Rigby MH, Bullock M, Trites J, Taylor SM, Hart RD: Hyperparathyroidism-jaw tumor syndrome. Head Neck 2013, 35:E175-E177.

25. lacobone M, Masi G, Barzon L, Porzionato A, Macchi V, Ciarleglio FA, Palu G, De Caro R, Viel G, Favia G: Hyperparathyroidism-jaw tumor syndrome: a report of three large kindred. Langenbeck Arch Surg 2009, 394:817-825. 
26. Raue F, Haag C, Frank-Raue K: [Hyperparathyroidism-jaw tumor syndrome. A hereditary form of primary hyperparathyroidism with parathyroid carcinoma]. Deutsche medizinische Wochenschrift 2007, 132:1459-1462.

27. Moon SD, Park JH, Kim EM, Kim JH, Han JH, Yoo SJ, Yoon KH, Kang MI, Lee KW, Son HY, Kang SK, Oh SJ, Kim KM, Yoon SJ, Park JG, Kim IJ, Kang HC, Hong SW, Kim KR, Cha BY: A Novel IVS2-1G > A mutation causes aberrant splicing of the HRPT2 gene in a family with hyperparathyroidism-jaw tumor syndrome. J Clin Endocr Metab 2005, 90:878-883.

28. Teh BT, Farnebo F, Kristoffersson U, Sundelin B, Cardinal J, Axelson R, Yap A, Epstein M, Heath H 3rd, Cameron D, Larsson C: Autosomal dominant primary hyperparathyroidism and jaw tumor syndrome associated with renal hamartomas and cystic kidney disease: linkage to 1q21-q32 and loss of the wild type allele in renal hamartomas. J Clin Endocr Metab 1996, 81:4204-4211

29. Mallette LE, Malini S, Rappaport MP, Kirkland JL: Familial cystic parathyroid adenomatosis. Ann Int Med 1987, 107:54-60.

30. Rekik N, Ben Naceur B, Mnif M, Mnif F, Mnif H, Boudawara T, Abid M: Hyperparathyroidism-jaw tumor syndrome: a case report. Annales d'endocrinologie 2010, 71:121-126.

31. Dinnen JS, Greenwoood RH, Jones JH, Walker DA, Williams ED: Parathyroid carcinoma in familial hyperparathyroidism. J Clin Pathol 1977, 30:966-975.

32. Cavaco BM, Guerra L, Bradley KJ, Carvalho D, Harding B, Oliveira A, Santos MA, Sobrinho LG, Thakker RV, Leite V: Hyperparathyroidism-jaw tumor syndrome in Roma families from Portugal is due to a founder mutation of the HRPT2 gene. J Clin Endocr Metab 2004, 89:1747-1752.

33. Schmidt BP, Bradrick JP, Gabali A: Hyperparathyroidism-jaw tumor syndrome: a case report. J Oral Maxillofac Surg 2009, 67:423-427.

34. Szabo J, Heath B, Hill VM, Jackson CE, Zarbo R, Mallette LE, Chew SL, Besser GM, Thakker RV, Huff V, Leppert MF, Heath H: Hereditary hyperparathyroidism-jaw tumor syndrome: the endocrine tumor gene HRPT2 maps to chromosome 1q21-q31. Am J Hum Genet 1995, 56:944-950.

35. Howell VM, Zori RT, Stalker HJ, Williams C, Jesse N, Nelson AE, Robinson BG, Marsh DJ: A molecular diagnosis of hyperparathyroidism-jaw tumor syndrome in an adolescent with recurrent kidney stones. J Pediatr 2004, 145:567.

36. Warnakulasuriya S, Markwell BD, Williams DM: Familial hyperparathyroidism associated with cementifying fibromas of the jaws in two siblings. Oral Surg Oral Med Oral Pathol 1985, 59:269-274.

37. Fujikawa M, Okamura K, Sato K, Mizokami T, Tamaki K, Yanagida T, Fujishima M: Familial isolated hyperparathyroidism due to multiple adenomas associated with ossifying jaw fibroma and multiple uterine adenomyomatous polyps. Eurn J Endocrinol 1998, 138:557-561.

38. Bradley ES Jr, Leake D: Ossifying fibroma involving the maxilla and mandible: report of a case. Oral Surg Oral Med Oral Pathol 1968, 26:605-614.

39. Takeda Y, Fujioka Y: Multiple cemento-ossifying fibroma. Int J Oral Maxillofac Surg 1987, 16:368-371.

40. Hauser MS, Freije S, Payne RW, Timen S: Bilateral ossifying fibroma of the maxillary sinus. Oral Surg Oral Med Oral Pathol 1989, 68:759-763.

41. Yih WY, Pederson GT, Bartley MH Jr: Multiple familial ossifying fibromas: relationship to other osseous lesions of the jaws. Oral Surg Oral Med Oral Pathol 1989, 68:754-758.

42. Khanna JN, Andrade NN: Giant ossifying fibroma. Case report on a bimaxillary presentation. Int J Oral Maxillofac Surg 1992, 21:233-235.

43. Hwang EH, Kim HW, Kim KD, Lee SR: Multiple cemento-ossifying fibroma: report of an 18-year follow-up. Dento Maxillo Facial Radiol 2001, 30:230-234.

44. Bertolini F, Caradonna L, Bianchi B, Sesenna E: Multiple ossifying fibromas of the jaws: a case report. J Oral Maxillofac Surg 2002, 60:225-229.

45. Barberi A, Cappabianca S, Colella G: Bilateral cemento-ossifying fibroma of the maxillary sinus. Brit J Radiol 2003, 76:279-280.

46. Stergiou GC, Zwahlen RA, Gratz KW: [Multiple cemento-ossifying fibromas of the jaw: a very rare diagnosis]. Schweiz Monatsschr Zahnmed 2007, 117:236-244

47. Chindia ML, Dimba EA, Moshy J, Limo A, Otwoma JG, Guthua SW: Synchronous occurrence of ossifying fibroma of the mandible and maxilla: a case report. Dent Update 2008, 35:705-707.

48. Ribeiro AC, Carlos R, Diaz KP, Gouvea AF, Vargas PA: Bilateral central ossifying fibroma affecting the mandible: report of an uncommon case and critical review of the literature. Oral Surg Oral Med Oral Pathol Oral Radiol Endod 2011, 111:e21-e26.
49. Akcam T, Altug HA, Karakoc O, Sencimen M, Ozkan A, Bayar GR, Gunhan O: Synchronous ossifying fibromas of the jaws: a review. Oral Surg Oral Med Oral Pathol Oral Radiol 2012, 114:S120-S125.

50. Agarwal N, Gupta P, Gupta P, Naik S, Upadhyay N: Recurrent bimaxillary radiopacities: a rare case report. Contemp Clin Dent 2012, 3:S103-S108.

51. Alsharif MJ, Sun ZJ, Chen XM, Wang SP, Zhao YF: Benign fibro-osseous lesions of the jaws: a study of 127 Chinese patients and review of the literature. Int J Surg Pathol 2009, 17:122-134.

52. Idowu BD, Al-Adnani M, O'Donnell P, Yu L, Odell E, Diss T, Gale RE, Flanagan AM: A sensitive mutation-specific screening technique for GNAS1 mutations in cases of fibrous dysplasia: the first report of a codon 227 mutation in bone. Histopathology 2007, 50:691-704.

53. Tabareau-Delalande F, Collin C, Gomez-Brouchet A, Decouvelaere AV, Bouvier C, Larousserie F, Marie B, Delfour C, Aubert S, Rosset P, de Muret A, Pages JC, de Pinieux G: Diagnostic value of investigating GNAS mutations in fibro-osseous lesions: a retrospective study of 91 cases of fibrous dysplasia and 40 other fibro-osseous lesions. Modern Pathol 2013, 26:911-921.

54. Bradley KJ, Cavaco BM, Bowl MR, Harding B, Cranston T, Fratter C, Besser GM, Conceicao Pereira M, Davie MW, Dudley N, Leite V, Sadler GP, Seller A Thakker RV: Parafibromin mutations in hereditary hyperparathyroidism syndromes and parathyroid tumours. Clin Endocrinol 2006, 64:299-306.

55. Sarquis MS, Silveira LG, Pimenta FJ, Dias EP, Teh BT, Friedman E, Gomez RS, Tavares GC, Eng C, De Marco L: Familial hyperparathyroidism: surgical outcome after 30 years of follow-up in three families with germline HRPT2 mutations. Surgery 2008, 143:630-640.

56. Guarnieri V, Bisceglia M, Bonfitto N, Cetani F, Marcocci C, Minisola S, Battista C, Chiodini I, Cole DE, Scillitani A: Re: Familial hyperparathyroidism: surgical outcome after 30 years of follow-up in three families with germline HRPT2 mutations. Surgery 2008, 144:839-840.

57. McCarthy EF: Fibro-osseous lesions of the maxillofacial bones. Head Neck Pathol 2013, 7:5-10.

58. Summerlin DJ, Tomich CE: Focal cemento-osseous dysplasia: a clinicopathologic study of 221 cases. Oral Surg Oral Med Oral Pathol 1994 78:611-620.

59. Su L, Weathers DR, Waldron CA: Distinguishing features of focal cemento-osseous dysplasia and cemento-ossifying fibromas: Il. A clinical and radiologic spectrum of 316 cases. Oral Surg Oral Med Oral Pathol Oral Radiol Endod 1997, 84:540-549.

60. Gunduz K, Avsever H, Karacayli U, Senel B, Piskin B: Florid cemento-osseous dysplasia: a case report. Braz Dent J 2009, 20:347-350.

61. Coleman H, Altini M, Kieser J, Nissenbaum M: Familial florid cemento-osseous dysplasia-a case report and review of the literature. J Dent Assoc S Afr 1996, 51:766-770.

62. Toffanin A, Benetti R, Manconi R: Familial florid cemento-osseous dysplasia: a case report. J Oral Maxillofac Surg 2000, 58:1440-1446.

63. Abdelsayed RA, Eversole LR, Singh BS, Scarbrough FE: Gigantiform cementoma: clinicopathologic presentation of 3 cases. Oral Surg Oral Med Oral Pathol Oral Radiol Endod 2001, 91:438-444.

64. Shah S, Huh KH, Yi WJ, Heo MS, Lee SS, Choi SC: Follow-up CT findings of recurrent familial gigantiform cementoma of a female child. Skelet Radiol 2012, 41:341-346.

65. Capodiferro S, Maiorano E, Giardina C, Lacaita MG, Lo Muzio L, Favia G: Osteoblastoma of the mandible: clinicopathologic study of four cases and literature review. Head Neck 2005, 27:616-621.

66. Hammas N, Laila C, Youssef ALM, Hind EF, Harmouch T, Siham T, Afaf A: Can p63 serve as a biomarker for giant cell tumor of bone? A Moroccan experience. Diagn Pathol 2012, 7:130.

67. Jain D, Jain VK, Vasishta RK, Ranjan P, Kumar Y: Adamantinoma: a clinicopathological review and update. Diagn Pathol 2008, 3:8.

68. Armah HB, McGough RL, Goodman MA, Gollin SM, Surti U, Parwani AV Rao U: Chondromyxoid fibroma of rib with a novel chromosomal translocation: a report of four additional cases at unusual sites. Diagn Pathol 2007, 2:44.

doi:10.1186/1746-1596-9-75

Cite this article as: Wang et al:: Two cases of multiple ossifying fibromas in the jaws. Diagnostic Pathology 2014 9:75. 